Article Type: Research Paper

\title{
Can the Ethical Orientation Mitigate the Manager's Earnings Management?
}

\author{
Priyastiwi $^{1 *}$, Sriwidharmanely ${ }^{2}$ and Krisnhoe Fitri Fatjriyati ${ }^{3}$
}

\begin{abstract}
:
Research aims: This study investigates the role of the ethical orientation of management in the relationship of asymmetry information and management status toward an individual's decision-making with respect to earnings management behaviors.

Design/Methodology/Approach: This methodology is an experimental method with $2 \times 2$ between-subject designs. 55 Accounting students from three private universities participated in 4 scenarios of cases (permanent and contractual management status, high and low asymmetry information) individually. Other side, the ethical orientation is measured, relativist and idealist. The Hypothesis was analyzed by ANOVA.
\end{abstract}

AFFILIATION:

${ }^{1}$ Department of Accounting, STIE Widya Wiwaha, Yogyakarta, Indonesia.

2 Department of Accounting, Faculty of Economics and Business, Universitas Bengkulu, Bengkulu, Indonesia.

\begin{abstract}
${ }^{3}$ Department of Accounting, Faculty of Economics and Business, Universitas Jendral Soedirman, Central Java, Indonesia.
\end{abstract}

\section{*CORRESPONDENCE:}

priyastiwi@yahoo.co.id

THIS ARTICLE IS AVAILABLE IN:

http://journal.umy.ac.id/index.php/ai

DOI: 10.18196/jai.2103157

\section{CITATION:}

Priyastiwi, Sriwidharmanely, Fatjriyati, K. F. (2020). Can the Ethical Orientation Mitigate the Manager's Earnings

Management?. Journal of Accounting and Investment, 21(3), 417-433.

\section{ARTICLE HISTORY}

Received:

30 Apr 2020

Reviewed:

1 Jun 2020

Revised:

14 Jul 2020

Accepted:

16 Jul 2020
Research findings: The ethical orientation influence managers' earnings management decisions. It can mitigate the influence of asymmetry information toward manager earning management decisions.

Theoretical contribution/ Originality: This research explains that earnings management behavior also can be explained by ethical approach, not only by using agency theory. Decision-makers will use ethical considerations when they are faced by the earnings management practices.

Practitioner/Policy implication: The results support pro-social theory that ethical orientation can influence the decision making when individuals are exposed to ethical dilemmas to make earning management.

Research limitation/Implication: Participants in this study used students, so they did not have experience. future studies can use professional participants and consider management status in more detail.

Keywords: Earnings Management; Ethical Orientation; Information Asymmetry; Management Status

\section{Introduction}

Earnings management is considered being management intervention towards the financial statements, in the form of accounting policy choices, which are permitted in the process of external financial reporting to achieve personal goals, thereby reducing the credibility of financial statements (Schipper, 1989). Earnings management can be considered as a misleading and deceiving act from shareholders (Healy \& Wahlen, 1999), or as an action that should be carried out by management (Beneish, 2001; Demski \& Sappingtont, 1987). There are some reasons why company managers do earnings management. Nabar and Boonlert-U-Thai (2007) conducted an international comparative study of investor's earnings and protection management from 1993 to 2003 with a sample of 33 countries 
including Indonesia. Based on the results of this study, Indonesia is in a group of countries with high average earnings management. Besides, the level of investor protection in Indonesia is considered relatively low.

Pennino (2002) states that managers are often faced with various dilemmas in decision making during the process and evaluation of ethical information. Decision making by considering ethical issues is named as ethical decision making such as earning management. From an ethical perspective, earnings management actions can be judged as an unethical action because it can reduce the accuracy of the financial statements that resulted in profit manipulating by the management. Some previous studies have shown that the tendency of managers to manage earnings from internal motivation (behavior) is influenced by several factors, which are pressure from the affiliates, altruistic and speculative motivation (Chen \& Tsai, 2010; Hamid, Hashim, \& Salleh, 2012), spirituality at work (Chen \& Sheng, 2013), individual attributes (emotional intelligence, narcissism, and moral disengagement) (Jones, 2013), ethical orientation (Greenfield, Norman, \& Wier, 2008; Jooste, 2013), and professional commitment (Greenfield et al., 2008).

This study investigated the role of the ethical orientation of managers to mitigate the tendency of them making the opportunistic earnings management decision inducing by their asymmetry information dan status. This study extended the research concept of Greenfield et al., (2008). Based on the prosocial behavior theory, this research proposes a manager's ethical orientation will control their behavior in managing earnings cause of asymmetry information and their manager status. Thus, The novelty of our study is the role of manager's ethical orientation, i.e., idealistic, based on the prosocial behavior theory toward an individual's decision-making with respect to earnings management behaviors. The prosocial behavior theory posits that managers with the idealistic orientation will tend to avoid making earning management, which can harm the others, rather than relativistic ones.

An individual is considered to be idealistic oriented when faces a moral decision within universal moral rules (Douglas, Davidson, \& Schwartz, 2001). When individuals dealing with an ethical dilemma, they will consider the possible hazards for all parties affected, because they focused on human well-being (Greenfield et al., 2008). Conversely, individuals who do not depend on universal moral rules when making moral judgments will believe that decisions can be ethical when they considered good and bad consequences. These individuals are considered as relativistic oriented. This theory is a positive form of social behavior, which shows any action taken by someone in providing benefit to. Ethical orientation influences the individual's attitudes and behavior, such as software hacking (Chan \& Lai, 2011), earnings management practices (Greenfield et al., 2008; Jooste, 2013), and moral judgment (Marques \& Azevedo-Pereira, 2009). others (Paulus, 2018).

Ethical judgments in situations of high moral intensity are affected by personal values and by environmental variables, such as the professional code of conduct and previous ethics instruction (Douglas et al. 2001). Related to asymmetry information, personal 
position characteristics and individual differences play an important role in income management decisions (Elias, 2002). Even though, there is no evidence of differences between contract and permanent managers in the decision-making process, for example in the control process (Hartmann \& Maas, 2010).

Based on the experience of individual professionals operating in this field, it showed that the managers who are being contracted are more effective in making profits, assertive, and are not interested in playing politics, more focusing on work, and being able to take initiative (Feltham \& Hughes, 1999). Thus, there are different personalities between contracted and permanent managers. However, there is no research examining yet the behavior of earnings management for the contract or permanent status of the managers. Meanwhile, the idealistic managers showed a lower slack creation behavior than the relativistic ones, as Greenfield et al. (2008) found that managers are more willing to respond to the situation by increasing their benefits.

Meanwhile, the agency theory (Jensen \& Meckling, 1976) states that asymmetry information is a condition in which agents have more information about the company and the prospects compared to the principal. Thus, earnings management occurs when the internal users (management) know the information about a company is better than external parties. This condition provides an opportunity for the agents to use the information they know to manipulate financial reporting to maximize their prosperity (Eisenhardt, 1989; Healy \& Wahlen, 1999). However, agency theory does not consider the fact that decision making is not only based on personal interests. Thus, this study filled this gap by employing the prosocial theory, i.e. ethical orientation as Greenfield et al., ( 2008) stated that there is a relationship between ethical orientation and the decision making. The manager as a human being also has ethics that will influence their decision making (Noreen, 1988).

This study confirms the role of managers' ethical orientation based on prosocial theory mitigating the willingness of them to make earning management caused by asymmetry information, but not management status. Moreover, this study could differentiate that the idealistic type of individual's ethical orientation plays a better role in mitigating earning management than the realistic one. This result provided further support for the prosocial theory that ethical orientation can influence decision making when individuals exposed to ethical dilemmas. This research explains that earnings management behavior also can be explained by the ethical approach, not only agency theory.

This research contributes to earnings management behavior and ethical literature by examining the role of ethical orientation toward earnings management behavior specially inducing by the asymmetry information. The main and interactions effect between ethical orientation and the asymmetry information level indicate that ethical orientation does play an important role in earnings management behavior. Thus, this study provides additional information to the management accounting literature and behavioral accounting regarding the earnings management, especially factors which influence the practice of earnings management. From a methodological view, this research contributes to the use of experimental design to treat the information 
asymmetry, ethical orientation and earnings management behavior that previously used archival data such as the calculation of discretionary accrual transactions (Dechow, Sloan, \& Sweeney, 1996).

\section{Literature Review and Hypotheses Development}

\section{Earnings Management}

Earnings management occurs when managers use judgment in financial reporting and in structuring transactions to alter financial reports to either mislead some stakeholders about the underlying economic performance of the company or to influence contractual outcomes that depend on reported accounting numbers (Healy \& Wahlen, 1999). While Schipper (1989) defined earning management as $E$ a purposeful intervention in the external financial reporting process with the intent to obtaining one private gain. Some studies view earnings management as a problem that needs an urgent remedy, while others consider it as a purposeful intervention to gain some private benefits (Dechow \& Skinner, 2000; Schipper, 1989). In this context, Beneish (2001) distinguished between opportunistic earnings management (to mislead investors) and informative earnings management (to portray a good image to the stockholders about a company's performance).

This study in the context of opportunistic earning management. Earnings information as a part of the financial statements is often used as the target of engineering through opportunistic management actions to maximize satisfaction but can harm shareholders or investors. Management as a company manager has more information about the company than the shareholders, so that asymmetry information occurs can enable management to practice accounting with profit orientation to achieve a certain performance. Agency conflicts that result in opportunistic management will result in a false reported profit, thus, it causes the company's value to decrease in the future. Management behavior to manage the profits according to their desires is known as earnings management.

These opportunistic actions are carried out by selecting certain accounting policies so that the company's profits can be regulated, raised, or lowered according to their wishes. Earnings management occurs when the manager chooses the reporting methods and inaccurately estimates and reflects the economic conditions of the company. The ability of the managers to use their own judgment and discretion in accounting gives them the power to choose any allowable accounting method and any estimate in accounting method (Dechow \& Skinner, 2000). The ways of managing earnings can through the use of accruals, income minimization, income maximization and income smoothing (Ghazali, Shafie, \& Sanusi, 2015). The likelihood of the techniques to be chosen as a tool to manage the earnings will depend on the motive of the management. 


\section{Asymmetry Information}

According to the agency theory (Jensen \& Meckling, 1976) , the agent and principal are separated. The separation of agents and principals raises asymmetric information. Both agents and principals have interests. Asymmetry information between agents and principals where agents have more information about the company's operating activities than principals is a basis for opportunistic agents to realize their interests. Agency theory assumes that the principal does not have enough information about the agent's performance. The agent has more information about self-capacity, work environment, the company, and prospects compared to the principal. This causes an imbalance of information held by the principal and the agents; hence, this condition is referred to as asymmetry information.

There is an assumption that each party acts to maximize itself, resulting in the agent to utilize the asymmetry information to hide some information that is not known by the principal. Asymmetry information and the conflict of interest that occur between the principal and agents encourage the agents to present information that is not true to the principal, especially if the information is related to the measurement of agent performance. The existence of asymmetry information between management (agent) and the owner (principal) can be an opportunity for the managers to take earnings management actions to trick the owners about the company's economic performance. The higher the asymmetry information between the manager (agent) and the owner (principal), the higher the motivation of the management to conduct earnings management actions.

Asymmetry information conditions will cause irregularities in financial statement information that is better known by the manager (agent) than the owner (principal) to fulfill their interests. These conditions can mislead users of the report in the decisionmaking process if the manager intentionally provides an inaccurate reporting of information through financial reports to the users including the principal. Stevens (2002) examine the budget gap by distinguishing 3 asymmetry information conditions, namely low, medium, and high. The results of this studies show that subordinates in high asymmetric information conditions tend to be higher in carrying out budget gaps (Hamid et al., 2012; Kaplan, McElroy, Ravenscroft, \& Shrader, 2007). Richardson (2000) found that the magnitude of information asymmetry affects the magnitude of earnings management practiced by managers. When information asymmetry is high, stakeholders do not have the necessary information to see through the managed earnings. When shareholders have insufficient resources, incentives, or access to relevant information to monitor manager's actions, earnings management can also occur (Schipper, 1989; Warfield, Wild, \& Wild, 1995). Thus, this study posit that the high asymmetry information will induce the manager to do earnings management more than the low one. Based on the explanation above, the following research hypothesis is formulated:

$\boldsymbol{H}_{1}$ : Managers with high asymmetry information tends to do earnings management compared to managers with low asymmetry information. 


\section{Management Status}

Management is the part of the company that designs and manages the company's operating activities to maximize the value of the company. There are temporary and permanent/regular status managers (Galup, Saunders, Nelson, \& Cerveny, 1997). Feltham and Hughes (1999) define temporary managers as professionals who offer their expertise in a limited time. While the permanent/regular manager is a professional who offers their expertise over a period that exceeds the temporary manager. Companies can use managers who are permanently employed, and managers based on contracts by the organization.

Most companies employ temporary managers for practical reasons, for example when a company seeks a temporary replacement for a manager who leaves, or when a manager is only tasked with completing a temporary, or recessionary, project, many managers leave the company, so the company loses experienced and skilled staff. However, nowadays, the position of temporary managers has changed in the functional role of providing objective and reliable financial statements, and it is responsible for the control systems within an organization, by supporting local decision-making processes and providing management information about operations.

Feltham and Hughes (1999) and Hartmann and Maas (2010) report that temporary managers have differences with permanent managers related to work style and personality. Besides, Matejka, Dunsing, and Walat (1998) state that management status can lead to unexpected behavior, such as creating slack, data misreporting and biasing accounting reports. Thus, this study posits that temporary management will have different act in earning management than the permanent one. Based on the explanation above, the following research hypothesis is formulated:

$\boldsymbol{H}_{2}$ : There is a difference in the behavior of earnings management between managers with temporary contract status compared to managers with permanent/regular status.

\section{Ethical Orientation}

At one or another time, a person must be involved in voluntary actions intended to help or benefit others and sometimes must ask for help from others when it is needed. This individual behavior is called prosocial behavior, which includes actions such as entertaining, saving, helping, and sharing. Meanwhile, prosocial behavior is all forms of positive action given to others without the desire to get rewards for self-interest (Forsyth, 2013). Prosocial behavior can be accompanied by psychological and social rewards; it means that individuals can benefit in the long run to live in a prosocial society (Roessler \& Perner, 2015).

Penner et al. (2005) show that there is convergent evidence that during the year children become good in various forms of pro-social activities that are quite sophisticated, such as helping, informing, and entertaining. Not only toddlers can do 
these things, but they also seem to do it regularly and are almost trustworthy. Meanwhile, individual ethical orientation will influence business decision making, such as the decision to manipulate earnings, i.e. relativist versus idealist. Individuals who tend to be more idealistic will decide not to manipulate earnings because they can cause harm to others, therefore, they tend to avoid (Forsyth, 2013). While Elias (2002) states that an idealistic ethical orientation would also assess earnings management actions as unethical actions, reflecting the prosocial behavior. On the other hand, those who tend to be relativistic consider the conditions beforehand rather than the potential risks resulted and tend to assess earnings management as an ethical act (Greenfield et al., 2008).

Forsyth (1980) develops the Ethics Position Questionnaire (EPQ) to identify an ethical orientation, which is described as a continuum with relativistic on one side and idealistic on the other. Forsyth (1980) explained that relativists describe individual focus for a set of rules or standards, while idealists focus on human well-being. Relativists refer to the extent to which an individual rejects universal moral rules that support subjective or situational approaches. This implies that individuals with high relativism will have a stronger tendency to reject the use of universal moral rules when making decisions, and vice versa. Idealism refers to the extent to which a person thinks that morally correct actions will always produce the desired results.

The impact of management status and asymmetry information on earnings management can differ between individuals, this is influenced by contextual factors inherent in individuals such as gender, personality type, a locus of control, and others. In this study, the contextual factors used are ethical orientation, namely relativism, and idealism. Greenfield et al., (2008) suggest a significant relationship between an individual's ethical orientation, i.e., relativistic and idealistic, and decision-making, earning management. Meanwhile, Douglas and Wier (2000) found that individuals with a idealistic ethical orientation were less likely to engage in budgetary slack creation. Thus, within inducing the theory of pro-social behavior, this study posits that manager's ethical orientation will control their behavior in managing earnings cause of asymmetry information and their manager status. Specifically, this study presumes that when the manager has idealistic orientation, they will tend to avoid the earning management caused by their status or asymmetry information, than the relativism one. Based on this explanation, the following hypothesis can be formulated:

$H_{3 a}$ : Earnings management behavior will be higher in managers with relativistic ethical orientation and temporary-contract status in comparison with managers with permanent status and idealistic ethical orientation.

$\boldsymbol{H}_{3 b}$ : Earnings management behavior will be higher in managers with permanent status and relativistic ethical orientation in comparison with managers with temporary status and idealistic ethical orientation. 
$\boldsymbol{H}_{4 a}$ : In high asymmetry information conditions, earnings management behavior will be higher in managers with relativistic ethical orientation compared to managers with idealistic ethical orientation.

$\boldsymbol{H}_{4 b}$ : In low asymmetry information conditions, earnings management behavior will be higher in managers with relativistic ethical orientation compared to managers with idealistic ethical orientation.

\section{Research Model}

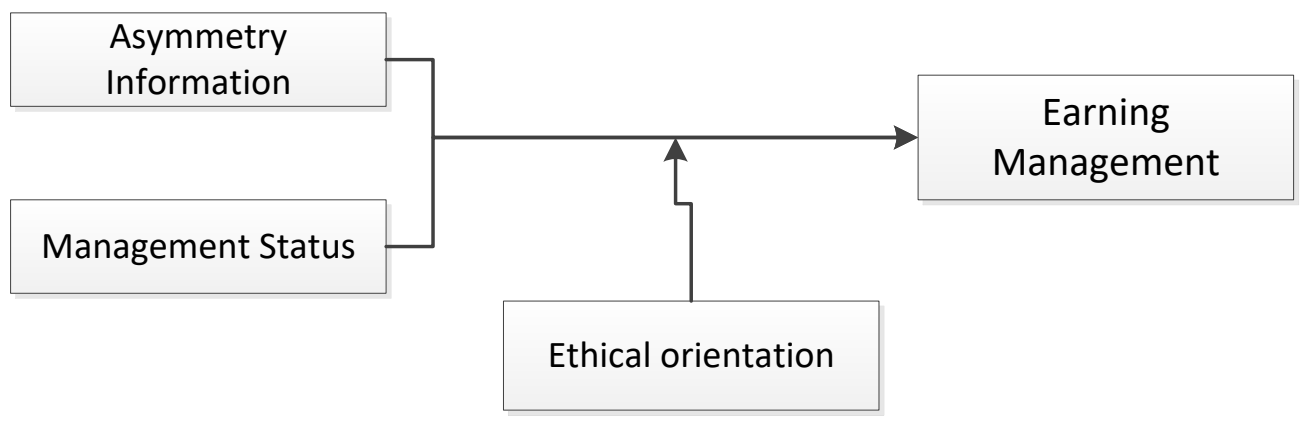

Figure 1 Research Model

\section{Research Method}

\section{Participants and check manipulation}

Participants who involve in this study are students majoring in Accounting Department who have taken Financial Accounting and Accounting Theory courses. Participants who are selected have knew financial accounting and financial reporting, in respect that they have a based knowledge in area that mostly earning management aoccurance. Participants are invited by email and voluntarily to take part in this experiment. In total of 61 students participated in this study. However, 2 students did not complete the experimental instrument and 4 students failed to be manipulated, so the number of final participants amounted to 55 people. Manipulation check is to test participants in understanding the concepts of asymmetry information and management status. Participants are given questions for each action with alternative answers from 1 to 10 . Participant answers are considered to have passed manipulation if more than $50 \%$ of the answers are correct.

The demographic data of the participants are as follows: male participants as amounted as $49.1 \%$ and women as amounted as $50.9 \%$. Participants aged $20-22$ years amounted to $52.7 \%$, while $23-24$ years was $47.3 \%$. From the analysis of different tests on average, there is no difference between men and women in supporting the decision to postpone treatment costs. Similarly, for the age of participants, there is no difference in earnings 
management behavior. This shows that gender and age do not affect earnings management decisions. Randomization is done by placing participants in each cell randomly without regard to participant demographics. Randomization tests were carried out using participants' demographic homogeneity tests. This was done to see that there were no differences in the demographic characteristics of the participants on the dependent variable. To control the effect of external variables on the dependent variable, it is carried out with the $\mathrm{F}$ test

The higher the sample size, the better for the researcher. However, there is a thumb sample size by some scholars. For example, experimental methodologies require at least 15 participants according to Cohen et al. (2007:102), and there should be at least 15 participants in control and experimental groups for comparison according to Gall et al. (1996). These references can be taken by researchers using small sample size.

\section{Research Design}

This research is experimental. With the $2 \times 2$ between-subject experiment design. The experimental process is carried out with an experimental laboratory. The experimenter distributes experimental material randomly. Case materials are designed to be based on paper and pencil and consist of informed consent, demographic data, case sketches, and ethical orientation questionnaires. The experimental design is done by manipulating the status of management (contract and permanent) and asymmetric information (high and low) of the participants. The number of participants for each cell is shown in Table 1.

Table 1 Participants

\begin{tabular}{lcccc}
\hline \multicolumn{2}{c}{ Management Status } & Contract & Permanent & Total \\
\hline Asymmetry & Low & 13 & 13 & 26 \\
Information & High & 13 & 16 & 29 \\
Total & & 26 & 29 & 55 \\
\hline
\end{tabular}

\section{Experimental Procedure}

Experiments were carried out by using paper and pencil. Because participants come from different universities, students are given a briefing on financial accounting through working on accounting problems about income statement to reduce history bias. The experimental task was randomized by giving a code number for each experimental group. Experimental instruments have been tested on students until participants can pass the manipulation check. Experimental tasks are divided randomly so that groups can be compared. A case is illustrated with short sentences and pictures, making it easier for participants to remember and understand. At the end of the case, the participants were asked to answer 2 questions which are used to check participants' understanding of the case given. Participants who answered incorrectly were excluded from the analysis. In the next session, students were asked to fill out questionnaires about the ethical orientation. At the end of the session, a debriefing was carried out to explain the purpose and objectives of the experiment. 


\section{Operationalization of Variables}

Independent Variables; There are three independent variables, asymmetry information, management status and ethical orientation. Those two variables are manipulated. Management status is manipulated as a manager with a temporary contract status or through a permanent career path. The asymmetry information is manipulated in high and low one; and the ethical orientation is the individual belief that considering to be right/ethic. This belief divided into relativistic and idealistic ethical orientation was measured using a questionnaire. This study adopted the Ethics Position Questionnaire (EPQ) developed by Forsyth (1980), to measure the ethical orientation of each participant. Questionnaires consisting of 20 questions, 10 each for idealistic and relativistic ethical orientation.

This research used the validity test of a product-moment correlation of 0.76 . While the reliability test was obtained by Cronbach's alpha reliability scores for 10 idealistic items and 10 relativistic items were 0.84 and 0.80 . For each participant, the average score of 10 idealistic question items and 10 relativistic statement items will be calculated. Participant classification is included in idealistic and relativistic ethical orientation based on the highest average answers.

Dependent variable: earnings management, in respect of individual decision to delay recognition of maintenance or maintenance costs. The measurement of earning management in this study adopted the scenario used by Clikeman and Henning (2000), that the respondents were asked to provide support or not the decision, to postpone treatment costs.

\section{Data Analysis Method}

This research used the ANOVA analysis method to test the hypothesis with more nominal independent variables at 2 levels. This analysis tool is used because there are more than 1 independent variable and nominal scale. Also, the dependent variable in this study is the interval scale. ANOVA is also used to test the interaction of independent variables and their influence on the dependent variable. There are 3 independent variables in this study, namely as asymmetry information, which is categorized as low and high; management status which is classified as contract and permanent status; and ethical orientation which is classified into idealistic orientation and relativistic orientation.

\section{Result and Discussion}

This study investigated the role of ethical orientation in the relationship between asymmetry information, management status, and earnings management. Hypothesis 1 predicts that managers with high asymmetry information will tend to do earnings management compared to managers with low asymmetry information. Table 3 shows the results of $\mathrm{H} 1$ testing, the main effect of asymmetry information shows the value of $\mathrm{F}$ 
$(3,135)$, P-value $=0.029$ (see table 3 . High asymmetry information results in an average decision to delay maintenance costs by $(M=4,851)$ compared to low asymmetry information ( $M=4,167)$. This shows that there are differences in earnings management decisions at high and low levels of asymmetry information. This result supports $\mathrm{H} 1$. In this study in accordance with previous research, Stevens (2002); Kraft, Lee, and Lopatta (2014); Kaplan et al. (2007), and Hamid, Hashim, and Salleh (2012) mention that high asymmetry information influences budgetary slack decisions, while this study states that high asymmetry influences earnings management behavior.

Hypothesis 2 predicts that there is a difference in earnings management behavior between managers with temporary-contract status compared to permanent/ regular management status. Table 3 shows the results of $\mathrm{H} 2$ testing, the main effect of management status shows the value of $F(2,451)$, P-value $=0,169$. Managers with temporary-contract status result in an average decision to postpone maintenance costs by $(M=4,521)$ compared to permanent manager status resulting in an average decision to delay maintenance costs $(M=4,496)$. This result does not support $H 2$. This showed that there is no difference in the management status that is contractual and permanent in supporting delays in maintenance costs. Hence, in a condition when the management conducting earnings management, it is not influenced by the status of management either permanently or contracted.

Hypothesis 3a states that earnings management behavior will be higher in managers with relativistic ethical-orientation and temporary-contract status in comparison with managers with permanent status of idealistic ethical orientation. The test results in table 3 show that the interaction between management status and ethical orientation results in a value of $F=2.128$, at the level of $p$-value $=0.122$. In Table 2 , it is shown that managers with temporary-contract status contract and relativistic ethical orientation resulted in an average decision to support a delay in treatment costs of 4,545 . While managers with permanent status with idealistic ethical orientation resulted in an average decision to postpone treatment costs with a mean of 4,400 . This shows that there is no difference in the decision to postpone treatment costs between temporarycontract status managers who have a relativistic ethical orientation and managers with permanent status with an idealistic ethical orientation so that $\mathrm{H} 3 \mathrm{a}$ is not supported. Whereas in hypothesis $3 b$ states that the behavior of earnings management will be higher in managers with a permanent contract and a relativistic ethical orientation in comparison with managers with an idealistic ethical orientation and temporary contract status. The test results show that the permanent managers with a relativistic ethical orientation produce an average decision to support a delay in treatment costs of 4.667 . While managers with idealistic ethical orientation contract status of 4,600. There is difference but not significant statically in the average decision to postpone treatment costs in managers with permanent status and relativistic ethical orientation compared to managers with idealistic ethical orientation and temporary contract status, so hypothesis $3 b$ is not supported. In Figure 2, it is explained that average earnings management is higher in managers with relativistic ethical orientation compared to managers with idealistic ethical orientation. This difference does not pay attention to the status of management, neither with contract status nor with permanent status. 
Priyastiwi, Sriwidharmanely \& Fatjriyati

Can the Ethical Orientation Mitigate the Manager's Earnings Management?

Table 2 Mean of Earnings Management Behavior and Standard Deviation

\begin{tabular}{llll}
\hline & & Relativistic & Idealistic \\
\hline Management Status & Temporary & $4.545(0.575)$ & $4.600(0.672)$ \\
& Permanent & $4.667(0.498)$ & $4.400(0.743)$ \\
Asymmetry Information & Low & $4.000(0.794)$ & $4.333(0.529)$ \\
& High & $5.017(0.654)$ & $4.684(0.557)$ \\
\hline
\end{tabular}

Hypothesis 4a states that in high asymmetry information conditions, earnings management behavior will be higher in managers with relativistic ethical orientation compared to managers with idealistic ethical orientation. The test results in table 3 show that the interaction between asymmetry information and ethical orientation produces a value of $F=4.269$, and $P$-value $=0.036$. In conditions of high asymmetry information, managers with a relativistic ethical orientation resulted in an average decision to delay maintenance costs by a mean of 5.017 higher than managers with idealistic ethical orientation with a mean of 4.684. This indicates that $\mathrm{H} 4 \mathrm{a}$ is supported.

Hypothesis $4 \mathrm{~b}$ states that when the asymmetry information conditions are low, earnings management behavior will be higher in managers with relativistic ethical orientation compared to managers with idealistic ethical orientation. The test results show the opposite result that when the asymmetry information is low, the managers with a relativistic ethical orientation produce an average decision to delay maintenance costs by a mean of 4,000 , lower than managers with idealistic ethical orientation with a mean of 4,333 . This indicates that $\mathrm{H} 4 \mathrm{~b}$ is not supported.

Figure 3, it describes the ethical orientation which shows that in managers with idealistic ethical orientation, the difference in average earnings management is low when there is a condition of low and high asymmetry information. Whereas in the managers with relativistic ethical orientation, profit management means the difference is higher between high and low asymmetry information conditions.

Table 3 Result ANOVA Test

\begin{tabular}{|c|c|c|c|c|c|}
\hline \multicolumn{6}{|c|}{ Dependent Variable: Earning Management } \\
\hline Source & $\begin{array}{l}\text { Type III Sum } \\
\text { of Squares }\end{array}$ & Df & Mean Square & $\mathrm{F}$ & Sig. \\
\hline Corrected Model & $6.565^{a}$ & 5 & 1.313 & .260 & .933 \\
\hline Intercept & 55.525 & 1 & 5.525 & 7.378 & .000 \\
\hline $\begin{array}{l}\text { Management } \\
\text { Status }\end{array}$ & 4.008 & 1 & 4.208 & 2.451 & .169 \\
\hline Asymmetry Inf & 5.727 & 1 & 5.727 & 5.135 & .029 \\
\hline Ethical Orientation & 4.006 & 1 & 4.006 & 1.276 & 0.00 \\
\hline Asymmetry * Ethic & 4.358 & 1 & 4.358 & 4.269 & .036 \\
\hline Status * Ethic & 4.644 & 1 & .644 & 2.128 & .122 \\
\hline Error & 7.144 & 49 & 7.144 & & \\
\hline Total & 81.412 & 55 & & & \\
\hline Corrected Total & 53.709 & 54 & & & \\
\hline a. R Squared $=0.36$ & Adjusted R Squar & .74) & & & \\
\hline
\end{tabular}


Estimated Marginal Means of Earnings Management Decision

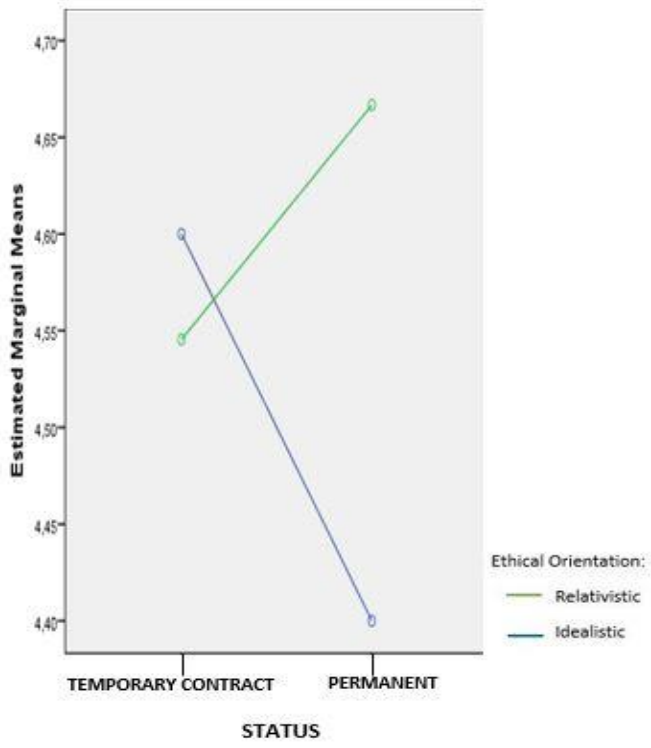

Figure 2 The interaction between Management Status and Ethical Orientation

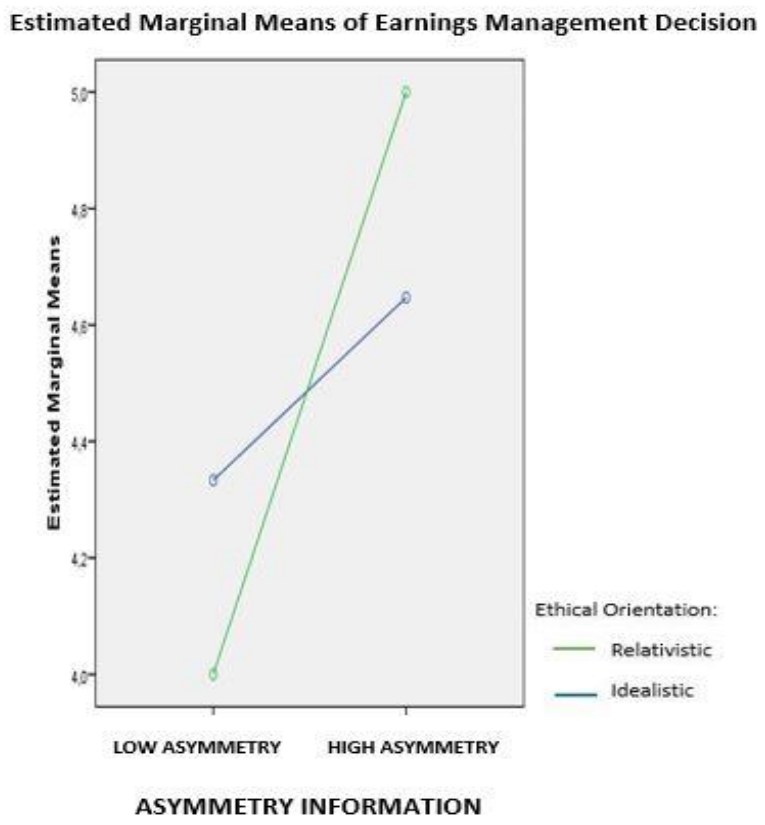

Figure $\mathbf{3}$ The interaction between the Asymmetry Information and Ethical Orientation

This study aims to examine the impact of management status and asymmetry information on earnings management decisions. Furthermore, this study examines whether individual ethical orientation, relativism, or idealism, influences the relationship between management status and asymmetry information toward earnings management. Asymmetry information influences the behavior of earnings management. 
High asymmetry information results in a decision to delay more cost of treatment than lower asymmetry information. Based on the agency theory, the opportunistic behavior of managers is motivated by an imbalance of information between agents and principals.

Management status does not affect earnings management behavior. Although the average decision to postpone treatment costs is higher in management with temporary contract status than management with permanent status, the difference is not significant. It can be concluded that the behavior of earnings management does not pay attention to their status as a temporary contract or permanent manager, but it is likely to be more driven by economic motives in the form of bonuses or compensation.

\section{Conclusion}

This study includes the ethical orientation that influences the relationship between the asymmetry information and management status to earnings management behavior. The test results using ANOVA analysis show that the behavior of earnings management in permanent status is higher in a condition of managers with relativistic ethical orientation than in idealistic ethical orientation, but these differences are not significant. The difference in the behavior of managers' earnings management in idealistic ethical orientation is smaller, even though they are in a temporary contract or permanent status. Therefore, it can be concluded that the behavior of earnings management is not influenced by the interaction of manager status and ethical orientation.

The results of testing the interaction of asymmetry information with ethical orientation indicate that in high asymmetry information, earnings management behavior is higher for relativistic managers than idealistic managers. Whereas in conditions of low asymmetry, average earnings management is higher for idealistic managers than relativistic managers. This shows that ethical orientation affects more on high asymmetry conditions. Whereas if conditions of asymmetry are low, ethical orientation does not affect. It can be concluded that ethical orientation partially affects asymmetry information. Based on the pro-social theory, the results of the study indicate that the behavior of the earnings management is influenced by the ethical orientation of managers depending on the condition of asymmetry information.

These findings explain that earnings management behavior can be explained by an ethical approach, not only by using agency theory. Decision-makers will use ethical considerations when they face earnings management practices. The results also support the pro-social theory that moral reasoning is the basis used for ethical decision making when individuals are facing an ethical dilemma.

The theoretical implication of research results is to provide empirical evidence that earnings management practices can not only be explained by agency theory but also empirically can be explained using the theory of pro-social behavior. The results of the 
study show that the creation of ethical policies in the field of accounting, especially in earnings management policies is influenced by ethical orientation.

This study has several limitations, namely: 1 ) participants in this study are undergraduate students, who may not be able to represent the behavior of managers to determine the behavior of earnings management. 2) In classifying the ethical orientation of the managers to be relativistic and idealistic using the average questionnaire answers, it might result in different classifications if this study uses the median of participants' quiz answers. 3) The case sketch used to manipulate the behavior of earnings management in this study is the decision to delay maintenance costs. Subsequent research can use other case sketches, which may affect different decisions.

\section{References}

Beneish, M. D. (2001). Earnings Management: A Perspective. Managerial Finance, 27(12), 3 29. https://doi.org/10.1108/03074350110767411

Chan, R. Y. K., \& Lai, J. W. M. (2011). Does ethical ideology affect software piracy attitude and behaviour An empirical investigation of computer users in China. European Joumal of Information Systems. https://doi.org/10.1057/ejis.2011.31

Chen, M. C., \& Tsai, Y. C. (2010). Earnings management types and motivation: A study in Taiwan. Social Behavior and Personality, 38(7), 955-962. https://doi.org/10.2224/sbp.2010.38.7.955

Chen, M.-C., \& Sheng, C.-W. (2013). Workplace Spirituality and Earnings Management Motivations. International Journal of Business and Information, 8(2), 267-299.

Clikeman, P. M., \& Henning, S. L. (2000). The Socialization of Undergraduate Accounting Students. Issues in Accounting Education (Vol. 15).

Dechow, P. M., \& Skinner, D. J. (2000). Earnings management: Reconciling the views of accounting academics, practitioners, and regulators. Accounting Horizons, 14(2), 235250. https://doi.org/10.2308/acch.2000.14.2.235

Dechow, P. M., Sloan, R. G., \& Sweeney, A. P. (1996). Causes and Consequences of Earnings Manipulation: An Analysis of Firms Subject to Enforcement Actions by the SEC. Contemporary Accounting Research, 13(1), 1-36. https://doi.org/10.1111/j.19113846.1996.tb00489.x

Demski, J. S., \& Sappingtont, D. E. M. (1987). Delegated Expertise. Journal of Accounting Research, 25(1), 68-89.

Douglas, P. C., \& Wier, B. (2000). Integrating ethical dimensions into a model of budgetary slack creation. Journal of Business Ethics, 28(3), 267-277. https://doi.org/10.1023/A:1006241902011

Douglas, P. C., Davidson, R. A., \& Schwartz, B. N. (2001). The effect of organizational culture and ethical orientation on accountants' ethical judgments. Journal of Business Ethics, 34(2), 101-121. https://doi.org/10.1023/A:1012261900281

Eisenhardt, K. M. (1989). Agency Theory: An Assessment and Review. Academy of Management Review, 14(1), 57-74. https://doi.org/10.5465/amr.1989.4279003

Elias, R. Z. (2002). Determinants of Earnings Management Ethics among Accountants. Journal of Business Ethics, 40, 33-45.

Feltham, R., \& Hughes, D. (1999). Interim Managers: Distinguishing Personality Characteristics of Managers on Short-term Contracts. International Journal of Selection and Assessment, 7(4), 209-214. https://doi.org/10.1111/1468-2389.00121 
Forsyth, D. R. (1980). A taxonomy of ethical ideologies. Journal of Personality and Social Psychology, 39(2), 175-184. https://doi.org/10.1037/0022-3514.39.1.175

Forsyth, D. R. (2013). Judging the morality of business practices: The influence of personal moral philosophies. In Citation Classics from The Journal of Business Ethics: Celebrating the First Thirty Years of Publication. https://doi.org/10.1007/978-94-007-4126-3 12

Galup, S., Saunders, C., Nelson, R. E., \& Cerveny, R. (1997). Thr Use of Temporary Staff and Managers in Local Government Environment. Communication Research, 24(6), 698730.

Ghazali, A. W., Shafie, N. A., \& Sanusi, Z. M. (2015). Earnings Management: An Analysis of Opportunistic Behaviour, Monitoring Mechanism and Financial Distress. Procedia Economics and Finance, 28(April), 190-201. https://doi.org/10.1016/s22125671(15)01100-4

Greenfield, A. C., Norman, C. S., \& Wier, B. (2008). The Effect of Ethical Orientation and Professional Commitment on Earnings Management Behavior. Journal of Business Ethics, 83, 419-453. https://doi.org/10.1007/s10551-007-9629-4

Hamid, F., Hashim, H. A., \& Salleh, Z. (2012). Motivation for Earnings Management among Auditors in Malaysia. Procedia - Social and Behavioral Sciences, 65, 239-246. https://doi.org/10.1016/j.sbspro.2012.11.117

Hartmann, F. G. H., \& Maas, V. S. (2010). Why business unit controllers create budget slack: Involvement in management, social pressure, and Machiavellianism. Behavioral Research in Accounting, 22(2), 27-49. https://doi.org/10.2308/bria.2010.22.2.27

Healy, P. M., \& Wahlen, J. M. (1999). A Review of the Earnings Management Literature and Its Implications for Stndard Setting. Accounting Horizons, 13(4), 365-383. Retrieved from https://search.proquest.com/docview/208900184/fulltextPDF/3BB5369943484C1D $\underline{\mathrm{PQ} / 1 \text { ? accountid }=13771}$

Jensen, M. C., \& Meckling, W. H. (1976). Theory of The Firm: Managerial Behavior, Agency Cost and Ownership Structure. Journal of Financial Economics, 3, 305-360. https://doi.org/10.1002/mde.1218

Jones, J. R. (2013). The Role of Individual Attributes in Earning Management Intention Decisions.

Jooste, L. (2013). Investigating Ethical Perceptions of Short-Term Earnings Management Practices. International Journal of Emerging Markets, 8(3), 282-299. https://doi.org/10.1108/17468801311330338

Kaplan, S. E., McElroy, J. C., Ravenscroft, S. P., \& Shrader, C. B. (2007). Moral judgment and causal attributions: Consequences of engaging in earnings management. Journal of Business Ethics. https://doi.org/10.1007/s10551-006-9226-y

Kraft, A., Lee, B. S., \& Lopatta, K. (2014). Management earnings forecasts, insider trading, and information asymmetry. Journal of Corporate Finance. https://doi.org/10.1016/i.jcorpfin.2014.03.002

Marques, P. A., \& Azevedo-Pereira, J. (2009). Ethical ideology and Ethical Judgments in The Portuguese Accounting Profession. Journal of Business Ethics, 86, 227-242. https://doi.org/10.1007/s10551-008-9845-6

Matejka, K., Dunsing, R. J., \& Walat, B. (1998). The seven habits of highly defective people. Management Decision, 36(10), 654-656. https://doi.org/10.1108/00251749810245309

Nabar, S., \& Boonlert-U-Thai, K. K. (2007). Earnings Management, Investor Protection, and National Culture. Journal of International Accounting Research, 6(2), 35-54. https://doi.org/10.2308/jiar.2007.6.2.35

Noreen, E. (1988). The Economics of Ethics: A New Perspective on Agency Theory. Accounting, Organizations and Society, 13(4), 359-369. https://doi.org/10.1016/0361$\underline{3682(88) 90010-4}$ 
Paulus, M. (2018). The multidimensional nature of early prosocial behavior: a motivational perspective. Current Opinion in Psychology, 20, 111-116. https://doi.org/10.1016/i.copsyc.2017.09.003

Penner., L. A., Dovidio., J. F., Piliavin., J. A., \& Schroeder., D. A. (2005). Prosocial Behavior: Multilevel Perspectives. Annual Review of Psychology, 56, 14.1-14.28. https://doi.org/10.1146/annurev.psych.56.091103.070141

Pennino, C. M. (2002). Is decision style related to moral development among managers in the U.S.? Journal of Business Ethics, 41(4), 337-347. https://doi.org/10.1023/A:1021282816140

Richardson, V. J. (2000). Information asymmetry and earnings management: Some evidence. Review of Quantitative Finance and Accounting, 15(4), 325-347. https://doi.org/10.1023/A:1012098407706

Roessler, J., \& Perner, J. (2015). Pro-social cognition: helping, practical reasons, and 'theory of mind.' Phenomenology and the Cognitive Sciences, 14(4), 755-767. https://doi.org/10.1007/s11097-015-9438-7

Schipper, K. (1989). Commentary on Earnings Management. Accounting Horizons, 3(4), $91-$ 102. https://doi.org/10.1002/9781118266298.ch24

Stevens, D. E. (2002). The Effects of Reputation and Ethics on Budgetary Slack. Journal of Management Accounting Research, 153-171. https://doi.org/10.2308/jmar.2002.14.1.153

Warfield, T. D., Wild, J. J., \& Wild, K. L. (1995). Managerial ownership, accounting choices, and informativeness of earnings. Journal of Accounting and Economics, 20(1), 61-91. https://doi.org/10.1016/0165-4101(94)00393-I 